\title{
Changes to the Regulatory Framework of the Chinese Rare Earth Industry after the Global Financial Crisis
}

\author{
ROLAND HOWANIETZ
}

\begin{abstract}
In the wake of the Global Financial Crisis, the Chinese government radically adjusted the regulatory framework of the domestic Rare Earth Elements (REEs) sector. This article investigates the reasons for regulatory adjustments and the impact on China's market power. The analysis of long-term REEs price and production trends illustrates four reasons for regulatory adjustments: the China discount, the need for industrial upgrading, growing domestic REEs demand and severe environmental pollution. The analysis of the effects of regulations shows that the restrictive trade regime has increased China's market power and ability to affect prices, which led to a redistribution of global welfare in favour of China. However, this market power is only temporary due to foreign countermeasures such as WTO-based allegations.
\end{abstract}

Keywords: Chinese resource policy; Rare Earth Elements; reregulation; trade regime adjustments; WTO.

\section{Introduction}

Amongst the general public, there is an acceptance that the prices for primary commodities in general and exhaustible resources in particular are steadily rising. Empirical studies do not fully support this view, instead showing different periods of varying price trends for natural resources (Cuddington \& Nuelle 2013; Slade 1982; Slade \& Thille 1997).

Historically, there have been at least six distinctive periods of general price trends for natural resources (Bundesamt fuer Umwelt 2010). ${ }^{1}$ From the beginning of the industrial revolution until the 1920s, prices increased slowly but steadily. In the period from the 1920s until 1970, the price curve for exhaustible resources took a u-shaped form due to first decreasing prices at the end of the First World War and during the Great Depression, followed by rising prices due to high demand in the Second World War, technological progress and declining purities of ex- 
ploited resources. The subsequent period from 1970 to 1984 was marked by extremely volatile prices fluctuations due to the first and second oil shocks. Higher efficiency in the use of resources, the development of substitutes and economic structural change all caused a stagnation of resource prices between 1985 and 2000. The high and fast rising demand of rapidly developing countries, such as the People's Republic of China (PRC) and India, led to constantly and rapidly increasing prices in the period from 2000 until the beginning of the Global Financial Crisis (GFC). During the GFC and its aftermath, resource prices experienced a sharp fall. In the current post crisis-period, a clearly observable price trend has not yet been identified.

Rare Earth Elements (REEs) ${ }^{2}$ prices underwent a contrasting development. REEs are a group of 15 metals with the atomic numbers 57 through 71, which form the lanthanide series. The metallic elements of Scandium and Yttrium do not belong to the lanthanide series but are incorporated in the REEs group in many studies because they have very similar physical-chemical properties (Humphries 2013; ${ }^{3}$ Hurst 2010; Information Office of the State Council 2012). ${ }^{4}$ REEs are called 'technology metals' or 'seeds of technology' because of their steadily increasing use in commercial applications in the fields of new energy technologies, high-technological consumer goods, industrial and medical appliances and national defense (Humphries 2013). In the period of rapidly increasing overall resource prices, the prices of these metals consistently decreased due to high supply levels from Chinese mines. Despite providing over 90 per cent of the total world supply since the 1990s the Chinese Rare Earth industry was not fully able to utilize its virtual monopoly. When prices for Rare Earth Minerals plunged during the GFC in 2008, Inner Mongolia Baotou Steel Rare Earth Hi-Tech Co Ltd realized losses while having a global market share of 50 per cent. This situation has given significant impetus for changes to the regulatory framework of the Chinese Rare Earth sector in order to raise the effective market power and REEs prices for the benefit of the domestic industry.

This paper aims to analyze the reasons for adjustments in the regulation of the Rare Earth industry in the PRC and its impact on REEs prices, market power and the global distribution of welfare. The remainder of the paper explores 1) the special characteristics of price formation for exhaustible resources based on the Ricardian approach and the Hotelling rule; 2) the potential impact of regulatory framework adjustments on prices; 3 ) the pre-crisis trends in REEs production and prices, along 
with the reregulation of the Chinese REEs industry in the wake of the GFC and its impact.

\section{Theory of Pricing of Exhaustible Resources}

Exhaustible resources are only available in finite stocks in nature and are thus absolute scarce. With ongoing exploitation and consumption, the scarcity of a specific non-renewable resource will rise over time, which leads to rising prices for the remaining stock of resources that are still unexploited in the ground. The neoclassical proposition that the optimal, welfare maximizing price for a good is equal to the marginal costs of production does not reflect the rising intertemporal scarcity and increasing shadow prices for unexploited resources in the ground. It is not applicable to absolute scarce and exhaustible resources (Perman et al. 2011).

David Ricardo (1817) formulated an approach that involved rising resource prices based on increases in extraction costs. In his model, he assumes that resource mines have different extraction costs due to differences in deposit sizes and ore grade. The resource stock with the lowest extraction costs is exploited first. Once this stock has been depleted or the total demand for the resource increases, the next mine with the second lowest extraction costs has to be developed, and so on. The increase of extraction costs leads to an increase of average costs for this resource and therefore to rising prices over time. According to Ricardo, the long-term supply curve for an exhaustible resource can be derived from the aggregation of costs and capacities of different mines. The course of this will only deviate in the case of the availability of new deposits with comparatively low extraction costs due to exploration and development, and extraction cost-reducing technological innovations (Ricardo 1817; Siebert 1985). However, the practical application of the Ricardian approach is difficult, particularly because of insufficient detailed information about the specific extraction costs of resource deposits (Bundesamt fuer Umwelt 2010).

Harold Hotelling (1931) proposed a model for optimal price paths for exhaustible resources, which is built on the idea of intertemporal scarcity. The central tenet of his model is that there has to be a temporal difference for mine owners in the decision to extract one unit of a resource in period $t$ or in period $t$ plus one. If a mine owner extracts and sells one unit today, $\mathrm{s} /$ he has the opportunity to invest the revenue on the capital market. The Hotelling rule for temporal indifference is thus 
an intertemporal efficiency condition that is satisfied when the market price for an exhaustible resource and the shadow price for remaining units in the ground increase at the discount rate. Mine owners with access to perfect future markets are able to extract their deposits so that the price increases with the discount rate in order to maximize the present value of their deposit (Hotelling 1931; Solow 1974; Perman et al. 2011). Extraction costs, which are the main determinant of price developments in the Ricardian approach, play a minor role in Hotelling's model and are assumed to be constant. When extraction costs are increasing over time due to stock effects and deposit grade deterioration, initial prices are set higher but will grow less rapidly compared to the case of constant costs (Pindyck 1977).

Empirical assessments of the Hotelling rule neither fully confirm nor reject it (Slade 1982; Slade \& Thille 1997). The poor empirical performance of the model is explained by its strict assumptions. Hotelling assumed a neoclassical framework without externalities or technological progress, with constant extraction costs, constant and known demand patterns, a perfect capital market, full information about the resource base and substitutes or backstop-technologies. Deviations from these underlying assumptions lead to major deviations of the real price path from the optimal price path (Solow 1974).

After consideration of the two models, it can be said that there is no single and simple approach to explain actual prices for exhaustible resources. Rather, there has to be an array of factors determining prices. The price-affecting role of government policies, which is not included in the models of Ricardo or Hotelling, will be discussed in the following section.

\section{Regulation of Exhaustible Resources and its Impact on Prices}

The regulatory policies of resource-producing countries can have direct or indirect impacts on resource prices. The first field of regulation illustrated here involves changes in the trade regime for non-renewable resources. Restrictive export instruments imposed on natural resources have been used since the period of mercantilism from the sixteenth to theeighteenth century, when French laws prohibited the exports of gold, which was used as the measurement of a country's wealth. However, these export controls were also used in other historical episodes, such as during the period of industrialization, the First and Second World Wars, and even 
in the era of trade multilateralism in the GATT-period before the foundation of the World Trade Organization (WTO) (Ribeiro 2014).

A possible first goal of export restriction is to directly influence prices. Large economies with significant market power are able to benefit from imposing export duties on goods that they are producing and exporting as the main supplier. The optimal export tax that will maximize the domestic welfare is thereby given by the inverse demand elasticity. The price for the resource on the world market will rise, while the domestic price will decrease. This benefits domestic consumers and disadvantages foreign consumers. Producers will face exactly opposite effects. Domestic producers experience an overall decrease of product prices, which induces a reduction of their welfare, of their production and of their employment, while foreign producers will experience an increase of prices for their products, of their output and of their employment. The export tax imposing government will receive additional tax revenues. Overall, the aggregate welfare effects are positive for the producing country and negative for importing countries. The imposition of export duties is thus a redistribution of global and domestic income and a welfare shift from foreign countries to the large economy (Devarajan et al. 1996; WTO 2010).

A second goal of restrictive trade regimes is tied to the dependency theory derived from the thesis of Prebisch (1950) and Singer (1950), which argue that the terms of trade of primary commodity exporting countries will deteriorate over time because the prices of primary commodities are declining in relation to the prices of manufactured goods. Primary commodity exporting countries, which are mainly developing countries, have to diversify their economic structure and the structure of their exports to be able to develop. Restrictions of the trade in resources are used in this framework as part of the industrial policy with the goal to build up a manufacturing sector with downstream industries. Instead of exporting low-value added resources, the shift to the export of highvalue added manufactured products should be achieved. Export taxes and export quotas raise the availability of needed resources and decrease the prices for domestic resource-processing industries.

The third goal of restrictive trade regimes is environmental protection and natural resource conservation. For this objective, quantitative restrictions are the most widely used measures to effectively limit the volume of traded resources. In the framework of GATT 1994/WTO, it is the only exception to the general prohibition of quantitative restrictions. Article XX of GATT 1994 justifies export restrictions on natural 
resources only when the restrictions actually result in a decrease of domestic resource production (Kim 2010).

The second field of regulation that affects prices on the global market is the regulation of domestic production. Instead of using export quotas, production quotas for specific exhaustible resources can be imposed with the goal to negatively influence the global and domestic availability in order to induce price increases. Taxes on the exploitation of resources also raise the price level of resources. Production quotas and resource taxes can also be used to reach environmental protection and natural resource conservation goals. As mentioned above, Article XX of GATT 1994 justifies export restrictions on natural resources under a constraint which is easier to achieve if restrictions on the domestic production are imposed at the same time (Kim 2010). If prices for exhaustible resources are suspected to be too low due to excessive production, the implementation of production licenses can reduce the number of producers and induce price increases. According to Hotelling (1931) and Stiglitz (1976), the annual rate of production will decrease with an increase of market concentration in the resource mining sector. The licensed producers exploit fewer units of resources at a higher price. As a side effect, the depletion point is postponed further into the future and the non-renewable resources are conserved for a longer time.

The third and final field of regulation discussed in this article is environmental regulation. In Hotelling's framework, externalities of resource production are nonexistent. Non-internalized social costs due to negative externalities related with resource extraction, such as water pollution or emissions of particulate matter, lead to market distortions and to lower prices and higher production than optimal. New and stricter environmental laws regarding emission level standards and production requirements might also induce an indirect price increase. Investment in abatement technology undertaken to comply with permitted emission standards is an additional cost driver that raises the average cost of extraction for all resource sources within the legal domain of the new law (Siebert 1990; Morgenstern et al. 2001). This leads to higher overall resource prices according to the Ricardian approach.

\section{Global Trends of Production and Pricing of Rare Earth Elements until the Global Financial Crisis}

The patterns of production and use of REEs have changed massively since the beginning of commercial exploitation for gas-mantle lamps in 
1880. When the USA started to produce gas-mantle lamps in 1902, the required REEs were imported first from Germany until the First World War, and then from India until REEs exports were embargoed in the course of India's independence. During this period, the usage of REEs had already shifted from mainly gas-mantle lamps to searchlights, motion-picture projectors and therapy-lamp carbons, in which REEs were used to enhance the intensity of light, and flints used in cigarette lighters. The loss of India as the supplier of 80 per cent of the US demand for REEs could be compensated for the discovery, exploration and development of the Mine Pass deposit in California (Goldman 2014). Figure 1 shows the production of Rare Earth Oxides from 1960 to 2010 in metric tons.

FIGURE 1: Global Rare Earth Element production, 1960-2010

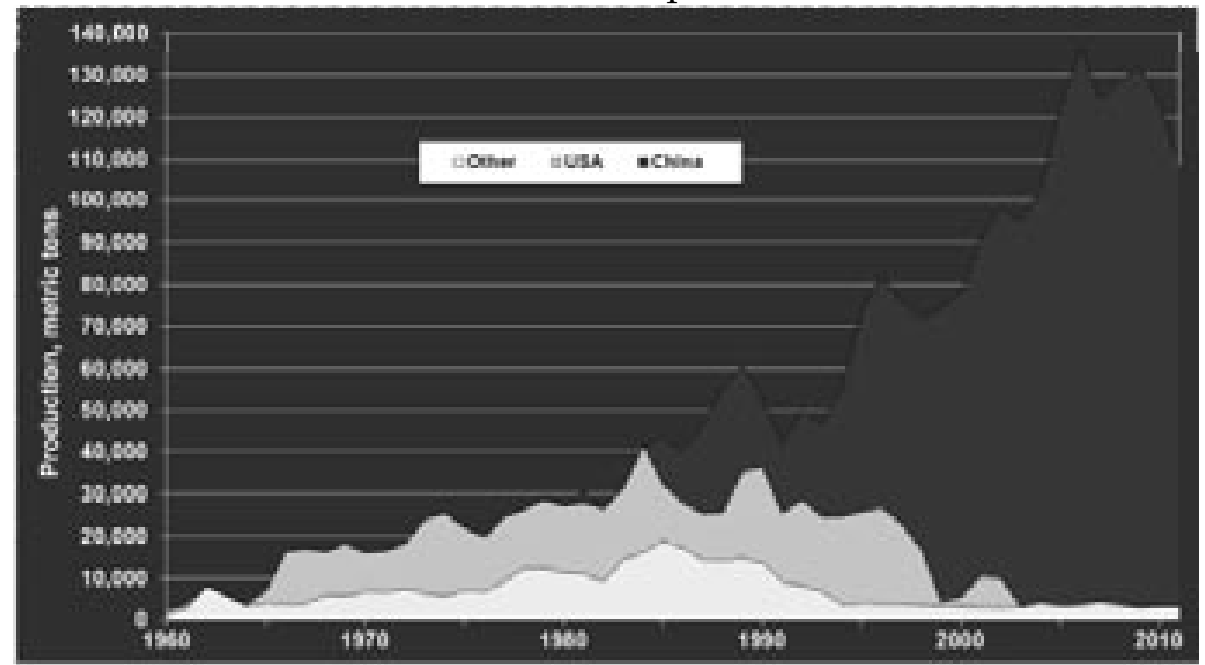

Source: USGS n.d. Global Rare Earth Oxide Production Trends ${ }^{5}$

The period until the mid-1960s is often dubbed the 'Monazite period' because REEs were primarily produced from monazite deposits. ${ }^{6}$ From 1965 to 1995, significant amounts of REEs were mined from the bastnaesite deposit in the Mountain Pass mine. At the climax of production, the USA did not only produce enough REEs to satisfy the domestic demand but was also able to supply one third of the demand in the rest of the world (Clagett 2013). The dominant positions of the USA in general and the Mountain Pass mine in particular were achieved through several factors. First, the ore grade of the Mountain Pass mine deposit was higher than in monazite deposits. This led to lower extraction costs. The preferred production in this mine is in line with the Ricardian approach (Humphries 2013). And second, the US government had actively supported the rise of the domestic REEs industry after the 
Second World War. In 1947, the Ames Laboratory was established and was subsequently financially supported by the governmental Atomic Energy Commission with the goal to conduct research in REEs production and application technology. New technology was directly transferred to the private REEs sector and further basic research in the public and private sector was supported by supplying high-purity rare earths. The foundation of the Rare Earth Information Center in 1966, with the goal to further connect the domestic and international rare earth sectors by offering information and consultation, finally consolidated the roles of Ames Laboratory and the USA for the global REEs industry (Goldman 2014). As seen in Figure 1, this dominant production position eroded from the second half of the 1980s and the PRC then became the major producer of REEs. Figure 2 illustrates the development of the REEs production of the PRC and its corresponding market share.

FIGURE 2: P.R.C. REE production and market share, 1984-2012

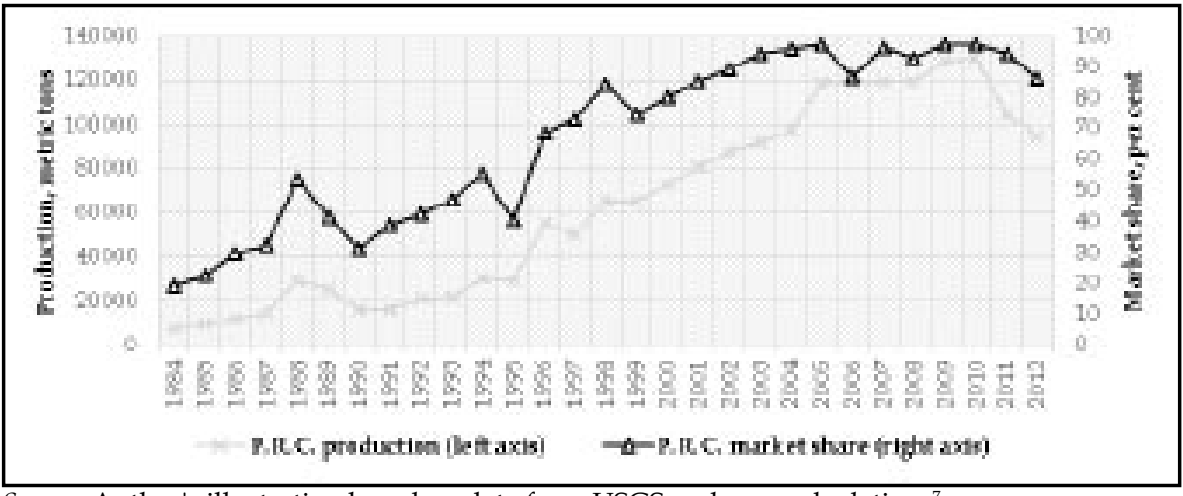

Source: Author's illustration based on data from USGS and own calculations ${ }^{7}$

With the beginning of political change and Deng Xiaoping's Open Door Policy, the global REEs community learned that the PRC possessed the largest REEs deposits with an estimated 36 million tons or 50 per cent of the world's reserves. In 1984, ${ }^{8}$ the PRC produced 8,000 metric tons of Rare Earth Oxides and had a share of just under 20 per cent of the global market. Both the amount of produced REEs and the market share increased rapidly and climaxed in the year 2010, in which the PRC had a global market share of 97.75 per cent. Since it has had a market share of over 90 per cent since 2002, China is said to have a virtual monopoly.

This shift of the dominant position in the REEs production from the USA to the PRC is the result of shifting comparative advantages that were partly driven by US domestic factors. In 1968, the US governmental support for the Rare Earth Information Center was suspended, but 
continued to provide information based on support from the private sector until 2002. After 1970, President Nixon initialized a paradigm change in environmental regulation and established the Environmental Protection Agency (EPA), which introduced strict pollution standards that put economic pressure on companies in the rare earth sector. In combination with lawsuits and EPA investigations of environmental contamination, these regulations forced a range of REEs firms out of business (Goldman 2014). The Mountain Pass mine was also affected by stricter environmental regulations. Between 1984 and 1998, the pipeline system that connected the mine with evaporation ponds suffered 60 spills of wastewater from the REEs extraction process that contained radiological and metallic constituents, which resulted in surface soil contamination (Ali 2014). This led to fines and costs for cleaning up the contaminated soil. In 2002, the Mountain Pass mine ran out of space to store its waste but was not permitted to build new storage. Because Molycorp, the company owning the Mountain Pass mine, was already under high competition pressure from the rising REEs industry in China at that point, it shut down completely (Morrison and Tang 2012).

The PRC ramped up the production of REEs between 1978 and 1989 with annual production growth rates of 40 per cent (Humphries 2013). REEs exports were primarily used to acquire foreign currency and to establish strategic ties with Western countries with the aim of gaining access to advanced technology. Domestic consumption did not increase in line with the increased production, so over 70 per cent of REEs production was produced solely for export until 2004. Beginning in 1985, the ad valorem tax of 16 per cent for REEs exports was fully rebated as a supportive measure (He 2014). The fast rising export levels induced a decline in global prices and put US and global REEs producers, as mentioned above, under serious economic pressure that they were ultimately unable to resist. The reestablishment of official diplomatic relations between the USA and the PRC in January 1979, the signing of a bilateral trade agreement in July 1979 and the provision of mutual most-favoured-nation treatment helped China to utilize low labour costs as one driver for comparative advantage in the REEs industry and therefore to boost exports.

Low extraction costs are another driver of production advantages. Although the ion-adsorption clay deposits in the Jiangxi and Fujian provinces and other areas in South China, which are the main source for heavy rare earths, ${ }^{9}$ have very low ore grades of only $0.05-0.2$ per cent, the exploitation is very economic because only low levels of investment 
and technology are needed for exploitation of this category of deposit. The Bayan Obo deposit of Inner Mongolia Baotou Steel Rare Earth HiTech Co Ltd is the world largest REEs mine and has a low ore grade of just one per cent. Yet the exploitation is economic because REEs are only mined as a byproduct from iron ore extraction and are recovered from the tailings of the primary mining activities (Golev et al. 2014). Low or even missing standards for emissions and labour conditions further cemented the cost advantage. Until 2010, Chinese mines were almost completely unregulated with regard to environmental issues (Clagett 2013). Last but not least, the shift of comparative advantage was also related to a shift in research and development activities. While private and public support of the Ames Laboratory declined in the USA, the PRC pushed domestic innovations in the field of REEs production and application. Although domestic demand was still low, REEs were seen as a strategic resource for the development of domestic high-tech capacities and were included in the National High Technology Research and Development Program (Program 863) in 1986 and the Basic Research Program 973 in 1997. Furthermore, specialized research institutions such as the State Key Laboratory of Rare Earth Materials Chemistry and Applications were founded to conduct basic or applied research. As a result of supported research, the Journal of Rare Earth and China Rare Earth Information, which are the only two journals to focus on REEs globally, are Chinese run (Hurst 2010). According to a study from Fifarek et al. (2008) that is based on patent data as a measure of innovative performance, the offshoring and re-localization of the US REEs production have also induced a loss of innovative capacity so that the USA has lost its technology leadership in REEs technologies. The PRC has now not only successfully developed new technologies for extraction and refining but has also overtaken the former role of the USA in high-tech end use applications like Neodymium permanent magnets, which are used in electric generators and electric motors.

To summarize, the global shift of production from the USA to the PRC was mainly driven by favourable conditions in China consisting of low extraction costs, low regulation costs, supportive trade policies and innovative superiority, which led to lower average costs of Chinese mines in line with the Ricardian approach. However, due to these lower average costs, the global prices were also low. Figure 3 shows the development of real prices for Rare Earth Oxides based on 1998 US dollar figures for the years 1922 to 2009. The growth rates have been calculated using logarithmic differences. Yet, the graph does not illustrate a trend 
FIGURE 3: Growth rates of REE real prices, 1922-2009

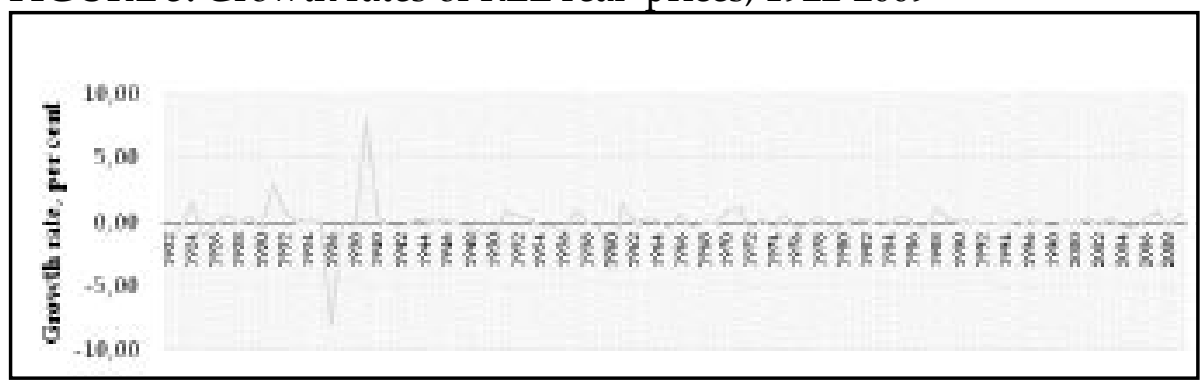

Source: Author's calculation based on data from USGS 2014

of steadily rising prices as the application of the Hotelling or Ricardo models would assume. The price fluctuations were extreme in the period from the beginning of the 1930s to the beginning of the 1940s. Yet, in the period after 1990, when the PRC gradually replaced the USA as major supplier and gained its virtual monopoly, price growth rates meandered around the zero line, nearly showing a real price stagnation.

This reflects the so-called 'China discount', which is defined as 'lower prices that result from excessive and disordered exports and the economic and non-economic measures taken by importers to force down the prices' (Zhang et al. 2015: 82). Despite its high market share, China was not able to affect prices due to missing market power and low domestic industry concentration. The supportive policies led to the entry of a high number of small companies, which extracted excessively in deposits in South China in particularly, where essential investment and extraction costs are low (He 2014). When prices for Rare Earth Minerals further plunged during the GFC in 2008, Inner Mongolia Baotou Steel Rare Earth Hi-Tech Co Ltd realized losses of 60 Million Renminbi (RMB) while having a global market share of 50 per cent (Zhang 2013). The elimination of the China discount was the first impetus for regulatory adjustments.

The real prices for industrial metals such as iron, zinc and copper grew especially from 1998 onwards due to the high demand of the PRC and India as emerging countries (Papp et al. 2008). The high prices for iron further promoted the mining of REEs as by-product in the Bayan Obo mine. This implies, ceteris paribus, a deterioration of China's terms of trade. According to the dependency theory, China should implement industrial policies with the goal to develop a REEs dependent downstream sector that produces and exports high-value added goods. This article identifies this as the second driver for changing the regulatory framework.

Another driver of regulatory adjustment is a change in the demandsupply balance. From 2005 to 2010, domestic REEs demand increased with annual average rates of 11 per cent while the demand in the rest 
of the world grew only with annual average rates of four per cent. The PRC is now the largest REEs consuming country in the world and needs a growing share of its production to satisfy domestic demand (Massari and Ruberti 2013). This is endangered by excessive extraction and exports. Based on a business-as-usual scenario for production rates and 2008 as the base year, some estimates suggest that the deposits in Bayan Obo and in South China could be depleted in 25 and ten years, respectively (Liu et al. 2013). Wang et al. (2015) estimates on the basis of the Generalized Weng Model, a curve-fitting model for extraction forecasting, that Chinese production will peak in the next ten years and will then decrease rapidly. After the peak, China would be dependent on massive REEs imports to satisfy demand. Therefore, the third factor for regulatory adjustment is the need to reduce exports and secure REEs supply for the domestic market.

The fourth driver is the need to finally regulate REEs-related environmental pollution, which is especially severe in villages near the Bayan Obo mine, where 'an increase in cases of cancer, respiratory diseases, dental loss, pollution of drinking water sources, with a radioactive risk of polluting the water of the Yellow River' (Massari \& Ruberti 2013:42) is observable. Emissions from REEs production do not only threaten the environment and human health but may also create non-internalized social costs that lead to market distortions and higher than optimal production.

\section{Reregulation in the Wake of the Global Financial Crisis}

Reregulation is defined as state involvement in the evolution of the market with the goal of controlling the market through the reformulation of old rules and the creation of new ones in order to achieve state goals (He 2014). The REEs sector in the PRC was not completely unregulated before the GFC but governmental agencies have tried to consolidate the industry and put an end to excessive mining several times. While high exports of REEs were a governmental goal in the 1980s and 1990s, supported by an effective export subsidy in the form of export tax rebates, companies needed to obtain licenses to be allowed to export. Production plans for three categories of REEs products and export quotas for rare earth products were imposed in 1990 and 1998 respectively, while the export of REEs for processing purposes was banned. In 1997, 1999 and 2006, permits for new mining or other REEs projects were temporally put on hold. The Ministry of Land, which was responsible for issuing and 
controlling production licenses, announced in 2004 that all unlicensed mines and operations would be shut down. Foreign direct investment in mining projects was also prohibited by the Chinese state but was encouraged in rare earth processing and downstream manufacturing Joint Ventures. With rising domestic demand, the tax rebates were abolished in 2005 and export duties of ten and 15 per cent were imposed one year later in order to hamper exports (He 2014).

These sequences of reregulation had the clear goal to restrict exports and to consolidate the sector by production licensing and controls. Yet, they were not successful. The actual exports exceeded the official export quotas due to smuggling of REEs. When export data reported by the PRC is being compared with import data reported by REEs importing countries, the reported REEs imports of 2006, 2007 and 2008 were 35, 59 and 36 per cent higher than the official exports in these years. Mines in South China are widely scattered across remote areas and are difficult to control (Information Office of the State Council 2012), so that they were often able to illegally continue extraction and exporting without gaining licenses. This is partly covered by local cadres who are dependent on the local REEs companies. The growth of the REEs industry has brought an increase of tax revenue, employment and local income, especially for provinces and regions that are economically underdeveloped. Because the Chinese cadre promotion system is based almost solely on economic development, the existing REEs sector as a major industry is being protected (Liu et al. 2013). Furthermore, local cadres acquire shares of local REEs companies in order to directly benefit from mining activities and therefore breach their original control duties (He 2014). In summary, the efforts to reregulate the REEs sector before the GFC were not successful because of diverging interests between the central government and local cadres, and the lack of power of the central government to enforce new regulations and laws.

After the mild attempts of reregulation before 2008, the urge for strong reregulation arose when the GFC affected China in 2008. The GFC demonstrated the need to transform the economic model from export-led to consumption-led growth in order to reduce export dependency and promote the decoupling from foreign business cycles. REEs-dependent, advanced downstream industries like the renewable energy sector were massively supported in the Chinese stimulus package. In order to protect REEs deposits from overexploitation and to ensure that REEs are rationally utilized, the Ministry for Land Resources issued the 'Guidelines of National Mineral Resources 2008-2015', which stated that 
exploration and production of exhaustible resources would be strictly controlled and overseen by the government. The issuance of new mining licenses was also suspended until 2015 (Morrison \& Tang 2012). ${ }^{10}$ The Ministry of Industry and Information Technology, which regulates the REEs industry as a whole, additionally drafted the 'Rare Earths Industry Development Plan 2009-2015', which was partly adopted and implemented. In order to put an end to illegal mining and smuggling, the government began a five-month long tour of supervising visits, which led to the closure of illegal mines and the arrest of mine operators (Seaman 2010) ${ }^{11}$ Furthermore, the regions with a REEs industry were grouped into three large mining districts with overall 11 sub-districts in order to tighten regulation and simplify management. The first district is located in Inner Mongolia, where the Bayan Obo deposit is, the second district is in Sichuan in Southwest China and the third one includes the ion-adsorption clay deposits in South China. The accumulated annual production of all districts should be in the range of 12,000 to 15,000 tons of refined metals, which is controlled by allocating production quotas (Schueler et al. 2011). These districts should also establish a pricing platform for unifying prices. In 2011, the Ministry of Finance and the State Administration of Taxation issued a rise of the resource tax for mining from $0.5-3 \mathrm{RMB} /$ ton to $60 \mathrm{RMB} /$ ton for light REEs and $30 \mathrm{RMB} /$ ton for heavy REEs (He 2014). In the same year, mergers and acquisitions in the REEs sector began to be promoted.

The final goal is to consolidate the industry into one large company per mining zone that vertically integrates the REEs activities of mining, separation and refining. These conglomerates would then be under direct control at the central governmental level. Local governments and local-government-controlled REEs firms are still heavily resisting these consolidation plans, so the enforcement of mergers and acquisitions is not assured (Biederman 2014; He 2014; Schueler et al. 2011). The consolidation is supported by new environmental regulations from the Ministry of Environmental Protection, which formulated emissions and pollution standards in the 2011 guidelines 'Emission Standards of Pollutants from Rare Earth Industry'. ${ }^{12}$ Companies that do not comply with these standards will be closed down and their production quota will be allocated to other companies (He 2014). The Baotou Rare Earth Hi-Tech Industrial Development Zone in Inner Mongolia, which was established in 1992, began to implement preferential policies in order to attract foreign direct investment and to assist investors in research and development programmes and the commercialization of new products (Biederman 2014). 
To summarize, the government of the PRC began to increase its control and to reregulate domestic production. These combined measures of consolidation, production quotas and elimination of illegal mining led to a consolidation of the industry into a highly concentrated sector where the central government is able to exercise market power through highly regulated state conglomerates. According to the Hotelling model, increased prices and decreased production would be the result.

The Chinese trade regime was concomitantly adjusted with the overall goal to export less REEs raw materials but more processed downstream products. Export licenses were reduced year after year. In 2006, 47 Chinese REEs producers and trading companies and 12 REEs Joint Ventures were licensed to export REEs. This number was reduced to only 22 Chinese firms and 9 Joint Ventures in 2009 (Tse 2011). Figure 4 shows the reduction of REEs export quotas in REEs equivalents from 2000 to 2014. Although there has been an overall reduction since 2006, the adjustment from 2009 to 2010 was a hard cut.

FIGURE 4: REE export quotas, 2000-2014

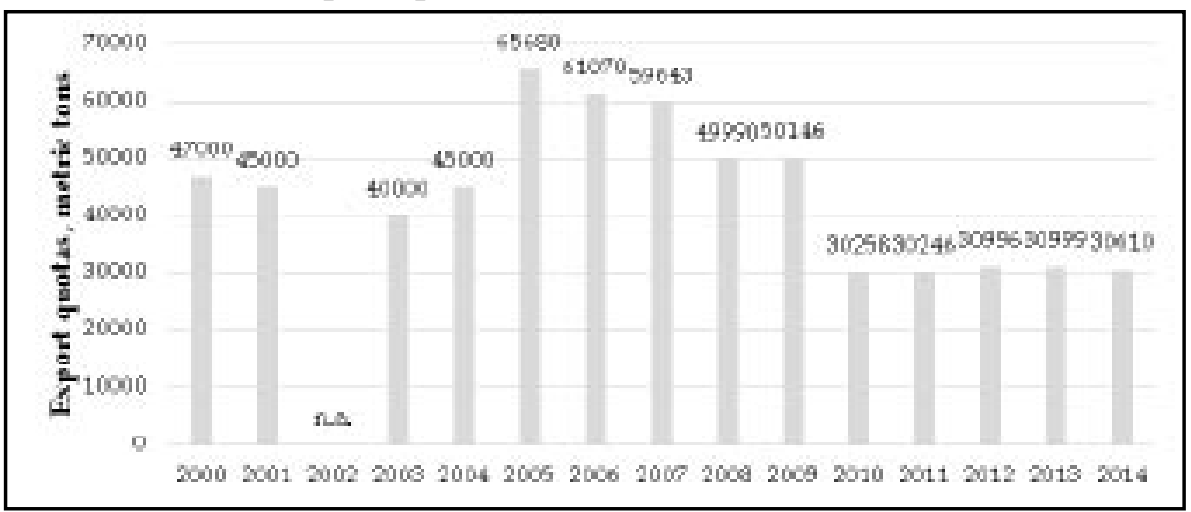

Source: Author's illustration based on data from Tse 2011 and Statista (2015) ${ }^{13}$

Although the PRC initiated several sequences of restrictive adjustments to the trade regime since 2005, the restriction that first attracted the attention of REEs importing countries was the export bans of 2010. After an incident related to the territorial dispute between the PRC and Japan regarding the Senkaku/Diaoyu Islands, China banned REEs exports to Japan, which is the second largest REEs consuming country after China, for two months. Additionally, China had also banned exports to the European Union and the USA from 18 until 28October 2010. While the ban was justified by the Chinese government as being the result of extensive industry inspections, the importing countries labelled it as economic warfare and a fall back towards mercantilism (Lackner \& 
McEwen-Fial 2011). ${ }^{14}$ This geopolitical event called into question the role of China as a reliable and secure source for REEs and also put its overall restrictive trade regime into the focus of Japan, the EU and the USA, which jointly filed an official WTO complaint against China. The WTO case following this complaint ruled in favour of the three accusing countries and maintained that China would have to abolish its trade restrictions (European Commission 2014). ${ }^{15}$

\section{Impact of Regulatory Adjustment on Pricing and Market Power}

The export ban of 2010 had a major impact on short-term REEs prices. While REEs prices plunged in 2009 because of the global recession and a slump in demand, they skyrocketed in 2010 and rose even further in 2011. The price for lanthanum oxide increased from $4.9 \mathrm{US} \$ / \mathrm{kg}$ to 22.4 US\$/ kg in 2010 and finally to 104.1 US\$/ kg in 2011, for example. This 21-fold increase was largely induced by a speculation bubble for REEs on the commodity markets. In 2012 and 2013, prices dropped again while being still higher than in 2008/2009 (Golev et al. 2014). The restrictive adjustments in the trade regime led to a significant difference between Chinese domestic prices and global prices. When REEs prices climaxed in 2011, price differences were between 68.5 to 557.2 per cent for some REEs (Morrison \& Tang 2012). According to Biedermann (2014), this dual pricing is perceived as a pressure on foreign companies to invest more in China, especially in high-tech sectors dependent on rare earths. As a result, 50 foreign companies are already operating in the Baotou Rare Earth Hi-Tech Industrial Development Zone in order to benefit from price discounts on REEs and tax exemptions (Biedermann 2014). Zhang et al. (2015) conducted a price sensitive analysis for REEs prices on the Japanese and U.S. markets in order to measure the changes of actual Chinese market power from 2001 to 2010. They conclude that market power and price sensitivity have increased by 140.18 per cent on the U.S. and by 244.22 per cent on the Japanese market, respectively, after tightening export restrictions so that China was able to obtain pricing power that it had previously failed to utilize in spite of its large market share (Zhang et al. 2015).

Mueller et al. (2014) estimate the wealth effects of export quota announcements for listed companies in the REEs industry in both China and the USA. Wealth effects are hereby measured in the form of abnormal returns, which are calculated as the residuals of regressing the 
individual companies' stock returns on the MSCI World index, which includes stocks from 23 developed markets and is commonly used as benchmark stock index. They came to the conclusion that extreme REEs price increases benefited Chinese companies in the upstream part of the REEs supply chain but were unfavourable for REEs users manufacturing in the USA. However, this result is only applicable to the pre-WTO trial period. With the beginning of the WTO trial, three rather than two quota announcements were issued each year, which were favourable for global REEs users and non-Chinese REEs suppliers (Mueller et al. 2014).

Pothen (2013) estimates the impact of REEs export restrictions on the Chinese market power and corresponding welfare effects by applying a dynamic partial equilibrium model. The business-as-usual simulation, which assumes export restrictions at the level of 2013, showed that China would be able to utilize its market power to affect prices until 2019. China's welfare gains are 1.4 billion US $\$$ in this scenario, while the rest of the world would incur welfare losses of 1.96 US\$. The end of Chinese market power in this scenario would be the market entry of REEs suppliers outside of the PRC (Pothen 2013). The development of new mines, the re-opening of old mines like the Mountain Pass mine, which can be economically exploited again due to high REEs prices, research and development efforts to find substitutes and recycling possibilities and the trade diversification of REEs suppliers were all triggered by the Chinese adjustment of the trade regime (Seaman 2012). ${ }^{16}$ Although restrictive trade policies have increased Chinese market power and the ability to affect REEs prices, market power is never static. China's market power is already challenged by foreign REEs consuming countries and their countermeasures.

\section{Conclusion}

This article sought to analyze the reasons behind regulatory adjustments targeting the Rare Earth industry in the PRC and its impact on REEs prices, market power and global distribution of welfare. In order to reach this goal, a theoretical framework about the pricing of exhaustible resources and the impact of regulation on prices was introduced. The four reasons that can explain why the PRC adjusted its regulatory framework for REEs domestic production as well as trade and environmental issues were 1) the China discount, which prevents China from utilizing its high market share for high market power, 2) the need to develop a high-value added REEs downstream industry due to the deterioration 
of the terms of trade as a result of resource trading, 3) the necessity to satisfy domestic REEs demand and 4) the need to internalize and limit REEs-related environmental pollution.

China implemented or tightened restrictive regulations for the domestic industry by revising the issuance of mining permits, the allocation of production quotas and the promotion of industry consolidation, for the export of REEs by reducing export quotas, raising export taxes and reducing export licenses, and for REEs-related emissions by implementing new environmental standards. The changes of the trade regime had an immediate impact on REEs prices and market power. With the help of export restrictions, China was able to temporarily eliminate the China discount, to gain market power, to affect prices and to skim off foreign welfare. In addition, increased foreign direct investment in REEs-related downstream industries is an early indicator that might show a first success on the way to upgrading the Chinese industrial structure. The effects of domestic consolidation could not be estimated because the process has just begun. Due to the WTO trial and other countermeasures that challenge the newly gained market power, this situation is short-lived. With the abolishment of the restrictive trade regime in 2015, the need to enforce the consolidation into central government-controlled conglomerates and thus the pressure on local governments resisting consolidation will rise. If industry consolidation were to be achieved it could renew the market power that the PRC temporarily enjoyed.

Roland Howanietz is a research associate at the Chair of East Asian Economics at the Ruhr University Bochum, Germany. He holds a Master in East Asian Economics from Ruhr University Bochum and obtained his PhD degree in Economics from Ruhr University Bochum in February 2017. His interests include the environmental policy and natural resources management of the People's Republic of China. Email: roland.howanietz@rub.de

\section{NOTES}

1 Bundesamt fuer Umwelt 2010. Preisentwicklung bei natuerlichen Ressourcen: Vergleich von Theorie und Empirie. http://www.bafu.admin.ch/publikationen/publikation/01520/index.html?lang=de. Accessed 3 April 2015.

2 REEs are also called Rare Earth Materials or Rare Earth Minerals (REM) interchangeably.

3 Humphries, Marc 2013. Rare earth elements: The global supply chain. CRS Report for Congress, http://www.fas.org/sgp/crs/natsec/R41347.pdf. Accessed 3 April 2015.

4 REEs are very heat resistant, maintain a strong magnetic field even under high 
pressure and have phosphorescent properties.

5 USGS n.d. Global Rare Earth Oxide Production Trends. Available at http://minerals. usgs.gov/minerals/pubs/commodity/rare_earths/ree-trends.pdf. Accessed 10 April 2015.

6 REEs deposits are categorized after their geological formations into 200 different types. The main deposit types are bastnaesite, monazite, ion-absorption minerals and xenotime. See U.S Environmental Protection Agency 2012.

7 See USGS 2012. Minerals Yearbook, Vol. 1994-2012. http://minerals.usgs.gov/minerals/pubs/commodity/rare_earths/index.html\#myb. Accessed 16 April 2016, and USGS 2014. Historical statistics for mineral and material commodities in the United States. http://minerals.usgs.gov/minerals/pubs/historical-statistics/. Accessed 16 April 2016.

8 The REEs production had already began earlier but 1984 is the earliest year for which detailed production data is available.

9 Heavy REEs are those with atomic number 64 through 71 plus Yttrium. Light REEs are those with atomic number 57 through 63. See Morrison and Tang 2012.

10 Morrison, Wayne M., and Rachel Tang 2012. China's rare earth industry and export regime: Economic and trade implications for the United States. CRS Report for Congress. www.fas.org/sgp/crs/row/R42510.pdf. Accessed 29 October 2014.

11 Seaman, John 2010. Rare earths and clean energy: Analyzing China's upper hand. Institut français des relations internationales. www.ifri.org/downloads/noteenergieseaman. pdf. Accessed 3 April 2015.

12 Ministry of Environmental Protection 2011. Xitu gongye wuran wupai fang biaozhun (Emission Standards of Pollutants from Rare Earths Industry). http://english. mep.gov.cn/standards_reports/standards/water_environment/Discharge_standard/201111/W020110210366768105784.pdf. Accessed 4 April 2015.

13 Statista 2015. China's rare earth element export quotas from 2005 to 2014 (in metric tons REO). http://www.statista.com/statistics/215216/chinese-rare-earth-elementexport-quotas/. Accessed 3 April 2015.

14 Lackner, Daniela, and Susan McEwen-Fial 2011. From resource advantage to economic superiority: development and implications of China's rare earth policy. Frankfurt Working Papers on East Asia 06/2011. http:/ / www.izo.uni-frankfurt.de/Veroeffentlichungen/Frankfurt-Working-Papers-on-East-Asia/WP_6-2011_Lackner_and_McEwen_Rare_earth_China.pdf. Accessed 29 October 2014.

15 European Commission 2014. WTO Appellate Body confirms: China's export restrictions on rare earths and other raw materials illegal. http:/ / europa.eu/rapid/press-release_ MEMO-14-504_en.htm. Accessed 6 April 2015.

16 Seaman, John 2012. Rare earths and the East China Sea: Why hasn't China embargoed shipments to Japan? Ifri-CIGS Op-Ed Series www.ifri.org/downloads/ifricanonopedseamanecs.pdf. Accessed 3 April 2015.

\section{REFERENCES}

Ali, Saleem H. 2014. 'Social and environmental impact of the Rare Earth industries'. Resources 3 (3): 123-134.

Biedermann, Reinhard P. 2014. 'China's rare earth sector- between domestic consolidation and global hegemony'. International Journal of Emerging Markets 9 (2): 276-293.

Clagett, Nichole 2013. 'A rare opportunity: Streamlining permitting for rare earth materials within the United States'. Journal of Energy and Environmental Law 4 (2), 123-138. 
Cuddington, John, and Grant Nuelle 2013. Variable long-term trends in natural prices. The ongoing tug-of-war between exploration, depletion, and technological change. Colorado School of Mines, Division of Economics and Business Working Paper No. 2013-02.

Devarajan, Shantayanan, Go, Delfin, Schiff, Maurice, and Suthiwart-Narueput, Sethaput 1996. The whys and why nots of export taxation. The World Bank Policy Research Working Paper No. 1684.

Fifarek, Brian J., Veloso, Francisco M., and Cliff I. Davidson 2008. 'Offshoring technology innovation: A case study of rare-earth technology'. Journal of Operations Management 26: 222-238.

Golev, Artem, Scott, Margaretha, Erskine, Peter D., Ali, Saleem H., and Grant R. Ballantyne, 2014. 'Rare earths supply chains: Current status, constraints and opportunities'. Resources Policy 41: 52-59.

Goldman, Joanne Abel 2014. 'The U.S. rare earth industry: Its growth and decline'. The Journal of Policy History 26 (2): 139-166.

$\mathrm{He}$, Yujia 2014. 'Reregulation of China's rare earth production and export'. International Journal of Emerging Markets 9 (2): 236-256.

Hotelling, Harold 1931. 'The economics of exhaustible resources'. Journal of Political Economy 39 (2): 137-175.

Hurst, Cindy 2010. China's rare earth elements industry: What can the west learn? Institute for the Analysis of Global Security, Washington, D.C.

Information Office of the State Council 2012. Situation and policies of China's rare earth industry. Beijing: Foreign Languages Press.

Kim, Jeonghoi 2010. Recent trends in export restrictions. OECD Trade Policy Papers No. 101, OECD Publishing.

Liu, Huifang, Lei, Lei, and Changxie Ye 2013. 'Study on rare earth management game between central and local governments in China'. Cross-Cultural Communication 9 (1): 31-35.

Massari, Stefania, and Marcello Ruberti 2013. 'Rare earth elements as critical raw materials: Focus on international markets and future strategies'. Resources Policy 38 (1): 36-43.

Morgenstern, Richard D.; Pizer, William A., and Jhih-Shyang Shih 2001. 'The cost of environmental protection'. The Review of Economics and Statistics 83 (4): 732-738.

Mueller, Maximilian, Schweizer, Denis and Volker Seiler 2014. Wealth effects of Rare Earth prices and China's Rare Earth Elements policy. Center for International Economics Working Paper Series No. 2014-13.

Papp, John F., Bray, E. Lee, Edelstein, Daniel L., Fenton, Michael D., Guberman, David E., Hedrick, James B., Jorgenson, John D., Kuck, Peter H., Shedd, Kim B., and Amy C. Tolcin 2008. Factors that influence the price of $\mathrm{Al}, \mathrm{Cd}, \mathrm{Co}, \mathrm{Cu}, \mathrm{Fe}, \mathrm{Ni}, \mathrm{Pb}$, Rare Earth Elements, and Zn. U.S. Geological Survey Open-File Report 2008-1356.

Perman, Roger, Ma, Yue, Common, Michael, Maddison, David, and James McGilvray 2011. Natural resource and environmental economics. Harlow: Pearson Education Limited.

Pindyck, Robert S. 1977. Optimal exploration and production of a nonrenewable resource. Massachusetts Institute of Technology Working Paper 77-013.

Pothen, Frank 2013. Dynamic market power in an exhaustible resource industry: The case of Rare Earth Elements. ZEW Discussion Paper No. 14-005.

Prebisch, Raul 1950. The economic development of Latin America and its principal problems. UN document no. E/CN.12/89/Rev.1.

Ribeiro, Gustavo Ferreira 2014. 'Export controls as industrial policy on natural resources regulatory limitations on China-raw materials and China-Rare Earths cases'. Brazilian Journal of International Law 12 (2), 78-92. 
Ricardo, David 1817. On the principles of political economy and taxation. London: John Murray.

Schueler, Doris, Buchert, Matthias, Liu, Ran, Dittrich, Stefanie, and Cornelia Merz 2011. Study on rare earths and their recycling. Oeko-Institut e.V. Final report for the Greens/EFA group in the European Parliament.

Siebert, Horst 1985. Ricardo- und Hotelling-Paradigmen fuer die Preisbildung natuerlicher Ressourcen. No. 205, Discussion Papers, Series I, University of Konstanz: Department of Economics.

Siebert, Horst 1990. 'Natuerliche Ressourcen und Weltwirtschaft'. Wissenschaftliches Archiv 126 (1): 1-14.

Singer, Hans Wolfgang 1950. 'The distribution of gains between investing and borrowing countries'. The American Economic Review 40 (2): 473-485.

Slade, Margarate E. (1982): 'Trends in natural-resource commodity prices: An analysis of the time domain'. Journal of Environmental Economics and Management 9: 122-137.

Slade, Margaret E., and Henry Thille 1997. 'Hotelling confronts CAPM: A test of theory of exhaustible resources'. The Canadian Journal of Economics 30 (3): 685-708.

Solow, Robert M. 1974. 'The economics of resources or the resources of economics'. The American Economic Review 64 (2), Papers and Proceedings of the Eighty-sixth Annual Meeting of the American Economic Association, 1-14.

Stiglitz, Joseph E. 1976. 'Monopoly and the rate of extraction of exhaustible resources.' The American Economic Review 66 (4): 655-661.

Tse, Pui-Kwan 2011. China's Rare-Earth industry. U.S. Geological Survey Open-File Report 2011-1042.

U.S. Environmental Protection Agency 2012. Rare earth elements: A review of production, processing, recycling, and associated environmental issues. Washington: Office of Research and Development.

Wang, Xibo, Lei, Yalin, Ge, Jianping, and Sanmang Wu 2015. 'Production forecast of China's rare earths based on the Generalized Weng model and policy recommendations'. Resource policy 43, 11-18.

World Trade Organization 2010. World trade report 2010: Trade in natural resources. Geneva: WTO.

Zhang, Lu, Guo, Qing, Zhang, Junbiao, Huang, Yong, and Tao Xiong 2015. 'Did China's rare earth export policies work? Empirical evidence from USA and Japan'. Resources Policy 43, 82-90.

Zhang, Shujing 2013. 'On problems in rare earth exports of China and countermeasures'. International Business and Management 6 (1): 21-25. 